\title{
The Importance of Working Discipline to Improve Employee's Working Productivity of Motor Vessel Manufacturing Company in Makassar Shipyard
}

\author{
Muhammad Arsyad \\ Maritime Academy of Veteran Republic of Indonesia (AMI) Makassar, Indonesia \\ E-mail: agustitantu@yahoo.com
}

Received: Nov. 13, 2014 Accepted: November 18, 2014 Published: December 26, 2014

doi:10.5296/bms.v5i2.7194 URL: http://dx.doi.org/10.5296/bms.v5i2.7194

\begin{abstract}
This study is conducted to know the influence of working discipline on employee's working productivity of a motor vessel industry, both simultaneously and partially, and to know some variables that influence their productivity. Factor analysis and double linier regression analysis are used in this study as the data analysis methods. The analysis shows that working discipline significantly influences employee's working performance simultaneously and partially.
\end{abstract}

Keywords: working discipline, performance, motor vessel industry 


\section{Introduction}

Fiber-based motor vessel industry grows rapidly, particularly for fishing vessel. Therefore, the companies or organizations strive to optimize their resources to take part in the competition. It is a challenge each company has to face. The companies must devise good strategies to maintain their competitive position in this competition by determining clear visions and missions as well as working more efficiently, effectively, and productively. Motor Vessel Industry in Makassar Shipyard is one of several companies whose vision and mission achievement requires optimum employee's working performance in providing service to its customers. It is one of several service companies that directly related to the customers. Therefore, it is necessary for the employees to provide their best service to the customers. Consumers' satisfaction reflects that the employees have done their best to provide the service.

Company's visions and missions can be achieved if the company can improve their employees' working performance. According to Murni (2007), company's performance level influences the company's profit. Sedarmayanthi (2010) stated that performance is the result of the employees and management process of the whole company in which the quantity or quality can be seen. Employees' working result can be assessed based on the performance standard which has been put on by the company. Their performance is considered as good if they give working performance that meet the company's standard.

Working discipline is one of several factors that influence employees' performance. Aryanti (2009) stated that discipline is the main factor that influences employees' working performance level. According to Ardana et al. (2011), working discipline is a combination of respect, appreciation, loyalty, compliance with applicable written and unwritten regulations; ability to carry it out; and accept the punishment. Iriani (2010) added that employee discipline is absolutely essential to make all activities run according to the mechanism. As a result, the employees will not commit any actions that result in company's disadvantages.

Other factor that influences employees working performance is leadership. According to Thoha (2010), leadership style is a norm used by someone to influence other's behavior in order to accomplish his objectives. Brahmasari (2008) mentioned that leadership is a process where a person becomes a leader based on continuous activities that influence other people he/she headed by to achieve company's or organization's objectives. Leadership style of an organization influences each employee's working performance. A leadership that in line with the situation and condition will motivate the employees to work more enthusiastically in performing their duties.

Another factor that also influences employees working performance is motivation. According to Sutrisno (2009), motivation is an attitude or stimulus which comes from within to do an activity. The importance of working motivation was presented by Handoko (2000), that it is a stimulus that influence employee's behavior in order to achieve his/her objectives and to find satisfaction. Shadare (2009) also stated that employee motivation is one of several 
strategies to improve employee performance. Due to the importance of motivation, it is necessary for an organization or company to have a positive motivation to achieve company's objectives.

Based on the described background of the problem, the researcher summarized his research context as follow: (1) Do the working discipline, leadership style, and working motivation significantly and simultaneously influence Makassar Shipyard employees' performance? (2) Do the working discipline, leadership style, and working motivation significantly and partially influence Makassar Shipyard employees' performance? (3) Among the variables of working discipline, leadership style, and working motivation, which one does dominantly influence Makassar Shipyard employees' performance?

This study is started from the following hypothesis:

1) Working discipline, leadership style, and working motivation are significantly influential to Makassar Shipyard employees' performance.

2) Working discipline, leadership style, and working motivation are partially influential to Makassar Shipyard employees' performance.

\section{Research Method}

Quantitative (positivism) approach, in associative form, is used in this study since it is aimed to know the influence of two or more variables. This study was conducted in Makassar Shipyard, which is located in Tallo District, Makassar. Respondents of this study were all of the shipyard's 47 employees. This study used primary data that consists of interview transcript, direct observation result, and questionnaire which were distributed to the respondents and secondary data that consists of the company's documents (company profile).

In order to determine the sample, the researcher used census method. Double linear regression analysis was used to answer the influence of independent variables (working discipline, leadership style, and motivation) whether or not they are influential simultaneously, partially, and dominantly to the dependent variable (employee performance).

\section{Findings and Discussion}

\subsection{Validity and Reliability Tests Result}

Based on the instrument test the researcher has done, it is concluded that all instrument items in this study are valid because the correlation coefficient has a score points more than 0.30 . The Reliability Test shows that the entire variables are considered as reliable because its Cronbach's Alpha score of each variable is higher than 0.6. 
3.2 Result of Double Linear Regression Analysis

Table 1. Result of Double Linear Regression Analysis

\begin{tabular}{|c|c|c|c|c|c|}
\hline \multirow[t]{2}{*}{ Variables } & \multicolumn{2}{|c|}{$\begin{array}{c}\text { Undstandardized } \\
\text { Coefficients }\end{array}$} & \multirow{2}{*}{$\begin{array}{c}\text { Standardized } \\
\text { Coefficients } \\
\text { Beta } \\
\end{array}$} & \multirow[t]{2}{*}{$\mathrm{t}$} & \multirow[t]{2}{*}{ Sig. } \\
\hline & B & Std. Error & & & \\
\hline Working Discipline & 0.298 & 0.064 & 0.298 & 4.681 & 0.000 \\
\hline Leadership Style & 0.418 & 0.061 & 0.418 & 6.802 & 0.000 \\
\hline Working Motivation & 0.332 & 0.060 & 0.332 & 5.545 & 0.000 \\
\hline Constant & \multicolumn{5}{|c|}{$=1.31 \mathrm{E}-0.15$} \\
\hline $\mathrm{R}$ & \multicolumn{5}{|c|}{$=0.916$} \\
\hline $\mathrm{R}^{2}$ & \multicolumn{5}{|c|}{$=0.839$} \\
\hline Adjusted RSquare Fcalculation & \multicolumn{5}{|c|}{$=0.834$} \\
\hline Sig. Fcalculation & \multicolumn{5}{|c|}{$=0.000$} \\
\hline
\end{tabular}

Source: Data, 2013.

The regression equation is shown below.

$$
\mathrm{Y}=-1.31 \mathrm{E}-0.15+0.298 \mathrm{X} 1+0.418 \mathrm{X} 2+0.332 \mathrm{X} 3
$$

Based on the regression result, it is concluded that:

1) Working discipline variable (X1) positively influences employees' performance variable (Y) with the coefficient value of 0.298 , which means that if the employees are discipline enough, their working performance will increase.

2) Leadership style variable (X2) positively influences employees' performance variable (Y) with the coefficient value of 0.418 , which means that if the leadership style is good, the employees' working performance will increase.

3) Working motivation variable (X3) also positively influences employees' performance variable $(\mathrm{Y})$ with the coefficient value of 0.332 , which means that if the employees' motivation is high,, their working performance will increase.

\subsection{Independent Variable's Simultaneous Influence Test on Dependent Variable}

Based on the F test, the Fcalculation is 149.712. It is higher than the Ftable (2.72), which means that the Ho is rejected. Therefore, it is concluded that working discipline, leadership style, and working motivation are significantly influential to Makassar Shipyard employees' 
performance. The obtained $\mathrm{R}^{2}$ value is 0.839 and it shows that $83.9 \%$ of Makassar Shipyard employees' performance variant is influenced by working discipline, leadership style, and working motivation, while the rest of it $(16.1 \%)$ is influenced by other variables.

\subsection{Independent Variable's Partial Influence Test on Dependent Variable}

1) Influence of Working Discipline upon Employee's Performance Working discipline is one of several factors that influence employees' performance. Iriani (2010) added that employee discipline is absolutely essential to make all activities run according to the mechanism. As a result, the employees will not commit any actions that result in company's disadvantages. It is stated in Amran's (2010) research that there is a significant influence of working discipline upon performance. The test result reveals that working discipline (X1) variable shows t-calculation value of 4.98, which is bigger than t-table of 2.069. Thus, the researcher concluded that working discipline is partially and significantly influential upon employee's performance positively.

2) Influence of Leadership Style upon Employee's Performance Leadership is a company's or organization's success key, because leader is the driving force of the whole company's resources. It is stated in Purnomo's (2008) research that there is a significant influence of leadership style upon performance. The test result reveals that leadership style (X2) variable shows t-calculation value of 2.080, which is bigger than t-table of 2.028. Thus, the researcher concludes that leadership style is partially and significantly influential upon employee's performance positively.

3) Influence of Working Motivation upon Employee's Performance According to Sutrisno (2009), motivation is an attitude or stimulus which comes from within to do an activity. Wahyudin and Djumino (2007) in their study reported that motivation is significantly and positively influential upon working performance.

\subsection{Independent Variable's Dominant Influence Test on Dependent Variable}

Based on the standardized coefficients beta, it is known that working discipline (X1) variable has beta coefficient of 0.298 , leadership style variable (X2) of 0.418 , and working motivation (X3) variable of 3.332. Consequently, it is concluded that leadership style is more dominantly influential to employee's performance than the other independent variables.

\section{Conclusion and Suggestion}

\subsection{Conclusion}

1) Working discipline, leadership style, and working motivation simultaneously and significantly influential to Makassar Shipyard employees' performance of $83.9 \%$ while the other $16.1 \%$ is influenced by other variables.

2) It is concluded that working discipline, leadership style, and working motivation are partially and significantly influential to Makassar Shipyard employees' performance. In other words, the better the employees' understand working discipline, the implementation 
of a good leadership style by the leader, and the motivation they have, the better their performance. In contrast, poor understanding on working discipline, bad leadership style, and low employee motivation reduce the quality of their performance.

3) Leadership style (X2) is a variable that dominantly influences employees working performance in Makassar Shipyard with the highest absolute standardized coefficient beta score.

\subsection{Suggestions}

1) A leader should be willing to listen to his/her employees' complaint because of the lowest score, in terms of score variable description and instruction behavior indicators. If a leader is unwilling to listen to his/her employees' complaints, it will cause a bad effect to employees' themself, such as regulations breaching by them (i.e. being absent without notice), not obeying their superior's instruction, and thus it lowers their productivity.

2) Makassar Shipyard management should supervise any task they assign to their employees, so that the assignments suit their employees' capability and meet company objectives.

3) The management should pay their attention more to the appreciation they give to the employees because, based on the variable's description, it has a lower score. It is better for the management to give some rewards for the employees' contribution to their company.

\section{References}

Agus. (2008). Work motivation positive and significant impact on employee job satisfaction. Dalam Journal Manajemen dan kewirausahaan, 10(2), 124-135.

Amran (2009). Effect on Performance Employee Discipline Work Office of Social Affairs Gorontalo. Journal Ichsan Gorontalo, 4(2), 2397-2413.

Ardana, I Komang, Ni Wayan Mujiati \& I Wayan Mudiartha Utama. (2011). Human Resource Management. First Edition: Graha Ilmu. Brahmasari, Ida Ayu dan Suprayetno.

Handoko, T. H. (2000). Manajemen. Yogyakarta : Badan Penerbit Fakultas Ekonomi.

Iriani, N. I. (2010). Intrinsic Motivation, Extrinsic Motivation, Discipline and Its Effect on Employee Performance work in Sambas District Education Office. Journal Aplikasi Manajemen, 8(2), 561-569.

Mitfah. (2010). Leadership in Management A Behavioral Approach, Ninth Matter. Jakarta : Penerbit PT Raja Grafindo Persada.

Murni, Nur Indah Hayati Lestari. (2007). The Relationship Between Leadership Styles on Employee Performance And Compensation PT. Imawi Benjaya (Tupperware Indonesia) Di Jakarta. Journal Manajemen Publik dan Bisnis, 74-90. 
Purnomo, J. (2008). Influence Leadership, Motivation, and Work Environment on Performance of Civil Servants at the Office of Forestry and Plantation Jepara. In Leadership and Work Environment, 1-11.

Sedarmayanthi. (2010). Human Resource Management Reforms and Civil Service Management. Bandung: PT. Refika Aditama.

Shadare, Oluseyi. A., \& Hammed, T. A. (2009). "Influence of Work Motivation, Leadership Effectiveness and Time Management on Employees' Performance in Some Selected Industries in Ibadan, Oyo State, Nigeria". European Journal of Economics, 1(16), 8-17.

Sutrisno, E. (2009). Manajemen Sumber Daya Manusia. Edisi Pertama. Jakarta Thoha.

Wahyuddin, M. dan D. (2007). Analysis Of Leadership And Motivation Employee Performance In Office of National Unity and Community Protection In Wonogiri. Journal Aplikasi Manajeman, 1(3), 1-19.

Zesbendri dan Anik Ariyanti. Effect of Work Discipline Against Employee Performance In Office Statistics Bogor Regency. Journal Aplikasi Manajemen, 1(2), 11-19.

\section{Copyright Disclaimer}

Copyright for this article is retained by the author(s), with first publication rights granted to the journal.

This is an open-access article distributed under the terms and conditions of the Creative Commons Attribution license (http://creativecommons.org/licenses/by/3.0/). 